\title{
A Critical Analysis of Diet Diversity among Infants and Young Children Aged 6-24 Months
}

\author{
Lavanya Nallasamy ${ }^{1 *}$, Usha Singh ${ }^{1}$ and Sunita Kumari ${ }^{2}$ \\ ${ }^{1}$ College of Community Science, Dr. RPCAU, Pusa, Samastipur, Bihar - 848 125, India \\ ${ }^{2}$ Subject Matter Specialist, KVK, Birauli, India \\ *Corresponding author
}

\begin{tabular}{|c|}
\hline Keywords \\
\hline $\begin{array}{l}\text { Dietary diversity } \\
\text { score, Infants and } \\
\text { young children, Food } \\
\text { groups, Milk and milk } \\
\text { products, Growth and } \\
\text { development }\end{array}$ \\
\hline Article Info \\
\hline $\begin{array}{l}\text { Accepted: } \\
\text { 10 July } 2019 \\
\text { Available Online: } \\
10 \text { August } 2019\end{array}$ \\
\hline
\end{tabular}

A B S T R A C T

For dietary status, growth, development and health, optimal feeding procedures are needed for infants and young children. In order to meet the difference in dietary demands transition foods need to be included in the diet. Diet diversity refers to all food groups being included in the diet. To assess food intake, a food intake questionnaire and a dietary recall method lasting 24 hours were used. Using the seven food groups, diet variety was calculated. ANOVA was used to compare means. Sixty infants and young children have been engaged in these studies. As household revenue rises, DDS has been discovered to be enhanced and is favorably associated with infant nutrition status. As DDS increased, with the exception of starch, the percentage of consumption in most food groups enhanced as everyone consumes starch from DDS 3. Milk and milk products among infants and young children with the greatest DDS were the most prevalent kinds of meal. At least 5 food groups are not received by 50 percent of children in their regular diet. If not, the macro and micro nutrients will certainly be in deficiencies that will affect the metabolic procedures that adversely affect the growth and development of children.

\section{Introduction}

Infancy is referred from birth to approximately 2 years of age. Young children are typically referred to infants at first year of life. Optimal feeding practices for infants and young children are necessary for nutritional status, growth, development and health. Breast milk is an important component for growth and development by providing required nutrients that serve the unique needs of the human infants such as poly unsaturated fatty acids, certain milk proteins and iron in readily absorbable form. It also contains immunological and bioactive substances, which is absent from commercial infant formulas, which also confer protection from bacterial and viral infection and aids in gut adaptation and development of infants (WHO/UNICEF, 1998).

After the age of 6 months, the baby grows and become more active, breast milk alone is insufficient to meet the full nutritional and 
psychological needs of the infants and young children. Transition foods need to be included in the diet to fulfill the gap in the nutritional requirements like iron and energy. Dietary diversity is strongly associated with household economic status.

Few studies have specifically addressed the association between dietary diversity and household socio-economic status (SES) and/or food security (Hatloy et al., 2000; Torheim et al., 2004; Hoddinott and Yohannes, 2002; Gittelsohn et al., 1998).

Diet diversity is referred to the inclusion of all food groups in the diet. The important 7 food groups which needs to be included in the diet infants and young children are 1) starchy staples (foods made from grains, roots or tubers); 2) legumes; 3) dairy(milk other than breast milk, cheese or yogurt); 4) meat, poultry, fish or eggs; 5) Vitamin A rich fruits and vegetables (pumpkin; red or yellow yams or squash; carrots or red sweet potatoes; green leafy vegetables, fruits such as mango, papaya or other local vitamin A rich fruits); 6) other fruits and vegetables (or fruit juices); and 7) foods made with oil, fat or butter (Arimond and Ruel, 2004).

Lack of diet diversity is considered as a serious problem among poor population. For vulnerable infants and young children, the problem is particularly critical because they are in need of energy and nutrient dense foods to meet out the healthy physical and mental health (World Bank data, 2016). If we fail to meet out the above requirement of infants and young children malnutrition (acute and chronic) will occur. Malnutrition is defined as the impairment of health due to deficiency, excess or imbalance of nutrients (Stratton et al., 2003). In chronic malnutrition hidden hunger is one of the important problems which defined as the micronutrient deficiency and it can be overcome by inclusion of variety in the diet especially different kinds of fruits and vegetables (Muthayya et al., 2013). Keeping all these points in view the present investigation is designed to study the food consumption frequencies and food diversity gap among infants and young children.

\section{Materials and Methods}

\section{Study area}

Bihar's child population distribution over the era of 0-6 was 38.4 percent. The sex ratio between them in 2011 was 935 women per 1000 men, which is very small relative to 942 women in 2001 per 1000 men. Particularly stunting chronic malnutrition was $48 \%$ higher among children under 5 years of age (National Family Health Survey-4, 2015-16)). 43.9 per cent of kids were followed by underweight and 20.8 per cent of kids were wasted. The current research was scheduled to be conducted in Bihar district of Samastipur. A purposeful selection was made of 38 districts in Bihar Samastipur. There are 20 blocks in Samastipur district, of which one block was purposely chosen, namely Pusa. Community Science College, a well-known center for transferring state-of - the-art food handling technologies, is located in the core of the Pusa block, so it was chosen.

\section{Sampling strategy}

Two villages (Deopar and Harpur) were chosen for the current inquiry from the chosen block. The village choice was based on a straightforward method of random sampling. Simple random sampling method has chosen 30 participants from each village. Those who belonged to the scheduled caste were chosen intentionally. Since the infants and young children's age bracket was 6-24 months, their mothers / guardians were chosen as participants and requested for schedules to be filled out. 


\section{Data collection}

A food intake questionnaire and 24-hour nutritional recall technique was used to evaluate food intake. Diet diversity was calculated by using the 7 food groups namely1) starchy staples 2) legumes; 3) dairy; 4) meat, poultry, fish or eggs; 5) Vitamin A rich fruits and vegetables; 6) other fruits and vegetables; and 7) foods made with oil, fat or butter. So the highest Dietary Diversity Score (DDS) was 7, for each food group eaten during the corresponding 24-hour span, one point was provided (Fig. 1) (Arimond and Ruel, 2004).

\section{Data analysis}

The information gathered was divided into separate classifications and categorized. The percentage, mean and p-value of each food group consumption based on diet diversity rating also calculated. To compare the means, ANOVA was used. P-value $<0.05$ was accepted as significant for all statistical tests (Jayawardena et al., 2013).

\section{Results and Discussion}

In this research, 60 infants and young children were involved. The dietary diversity rating was shown in Table 1 in regards to sociodemographic features and health status. DDS improved when the child's age rose to 3.63 per cent for 6-12 months, 4.94 per cent for 13-18 months, and 5.93 per cent for 19-24 months. In the event of gender DDS of boys (4.79\%) and girls $(4.28 \%)$ were more or less the same.

DDS also discovered to be more or less the same in nuclear $(4.49 \%)$ and extended family (4.67\%) according to the household sort. Infants and young kids attached to the medium-sized family had the DDS of 5.17 per cent which was greater than infants and young children belonged to the small family (4.44\%). In the event of household revenue, DDS rose with rises in household revenue, as in the event of infants and young children belonging to very small revenue households, DDS was 3.80 per cent smaller than infants and young children referred to small (4.83\%), high $(5.18 \%)$ and very high $(5.71 \%)$ revenue households. While reviewing the health condition, kids belonging to wasted and underweight were discovered to have very small DDS (3.09\%) relative to infants and young children of wasted; stunted \& underweight $(4 \%)$, wasted $(4 \%)$, stunted \& underweight $(4.60 \%)$, Stunted $(5.06 \%)$ and Normal $(5.33 \%)$. It is in line with the research undertaken by Arimond and Ruel (2004) that the assessment of information from the Demographic and Health Survey (DHS) shows that dietary diversity is usually correlated with the status of child nutrition and that the connection stays when it comes to household wealth and welfare variables. Thus the positive association between dietary diversity and nutrition for children and household earnings was discovered.

According to the educational level of the parents, the DDS of infants and young children improved when the educational standard rose from 4.64 and 4.52 per cent for families who were illiterate and 5.50 and 5.71 per cent for parents who were graduated.

Whereas the occupation of parents in children belonged to mothers who worked as JeevIka and fathers who didn't seem to work as agricultural labor and landless labor were found to be higher in DDS as 5.83 and 6.11.

Table 2 demonstrates the DDS-based allocation trend of food consumption among children from different food groups. There was a minimum DDS of 1 and a peak of 7 . As DDS rose, the proportion consumption in most food groups was improved with the exception of starch as everyone consumes starch from DDS 3. 
Table.1 Mean, SD and P-value of dietary diversity score (DDS)

\begin{tabular}{|c|c|c|c|c|}
\hline \multirow{2}{*}{\multicolumn{2}{|c|}{ Characteristics }} & \multicolumn{3}{|c|}{ DDS } \\
\hline & & \multirow{2}{*}{$\begin{array}{c}\text { Mean } \\
3.63\end{array}$} & \multirow{2}{*}{$\begin{array}{c}\text { SD } \\
1.73\end{array}$} & \multirow{4}{*}{$\begin{array}{l}\text { P value } \\
<0.001\end{array}$} \\
\hline \multirow{3}{*}{ Age } & 6 to 12 & & & \\
\hline & 13 to 18 & 4.94 & 1.57 & \\
\hline & 19-24 & 5.93 & 0.73 & \\
\hline \multirow{2}{*}{ Gender } & Boy & 4.79 & 0.83 & \multirow{2}{*}{0.27} \\
\hline & Girl & 4.28 & 2.29 & \\
\hline \multirow[t]{2}{*}{ Family type } & Nuclear & 4.49 & 1.78 & \multirow[t]{2}{*}{0.79} \\
\hline & Extended & 4.67 & 1.80 & \\
\hline \multirow[t]{2}{*}{ Family size } & Small & 4.44 & 1.83 & \multirow{2}{*}{0.35} \\
\hline & Medium & 5.17 & 0.98 & \\
\hline \multirow[t]{2}{*}{ Food habits } & Non-veg & 4.51 & 1.74 & \multirow[t]{2}{*}{0.91} \\
\hline & Veg & 4.60 & 2.30 & \\
\hline \multirow{4}{*}{ family income } & Very low & 3.80 & 1.11 & \multirow[t]{4}{*}{0.01} \\
\hline & Low & 4.83 & 1.88 & \\
\hline & High & 5.18 & 1.07 & \\
\hline & Very high & 5.71 & 2.14 & \\
\hline \multirow[t]{6}{*}{ Health status } & Stunted & 5.06 & 1.30 & \multirow[t]{6}{*}{0.02} \\
\hline & Wasted & 4.00 & 2.68 & \\
\hline & Wasted \& Underweight & 3.09 & 1.70 & \\
\hline & Stunted \& underweight & 4.60 & 1.34 & \\
\hline & Wasted, stunted \& underweight & 4.00 & 1.67 & \\
\hline & Normal & 5.33 & 1.50 & \\
\hline \multirow[t]{5}{*}{ Father's education } & Illiterate & 4.64 & 1.47 & \multirow[t]{5}{*}{0.41} \\
\hline & Middle & 4.12 & 1.87 & \\
\hline & Matric & 4.00 & 2.00 & \\
\hline & Intermediate & 4.20 & 3.03 & \\
\hline & Graduate & 5.50 & 1.31 & \\
\hline \multirow[t]{5}{*}{ Mother's education } & Illiterate & 4.52 & 1.41 & \multirow[t]{5}{*}{0.02} \\
\hline & Middle & 3.44 & 2.03 & \\
\hline & Matric & 4.52 & 2.03 & \\
\hline & Intermediate & 5.11 & 1.25 & \\
\hline & Graduate & 5.71 & 1.77 & \\
\hline \multirow[t]{3}{*}{ Father's occupation } & Landless labour & 4.48 & 1.61 & \multirow[t]{3}{*}{0.005} \\
\hline & Agricultural labour & 3.85 & 1.87 & \\
\hline & Others & 6.11 & 1.05 & \\
\hline \multirow{3}{*}{ Mother's occupation } & Home maker & 4.83 & 1.94 & \multirow[t]{3}{*}{0.13} \\
\hline & Jeevika & 5.83 & 1.17 & \\
\hline & Labour & 4.31 & 1.76 & \\
\hline
\end{tabular}


Table.2 Per cent consumption of different food groups by dietary diversity score ( $\mathrm{n}=60)$

\begin{tabular}{|l|c|c|c|c|c|c|c|}
\hline DDS & $\mathbf{1}$ & $\mathbf{2}$ & $\mathbf{3}$ & $\mathbf{4}$ & $\mathbf{5}$ & $\mathbf{6}$ & $\mathbf{7}$ \\
\hline No. of Infants and young children & 9 & 0 & 1 & 16 & 14 & 15 & 5 \\
\hline Percentage & 15.00 & 0.00 & 1.67 & 26.67 & 23.33 & 25.00 & 8.33 \\
\hline Food groups & 0.00 & 0.00 & 100.00 & 100.00 & 100.00 & 100.00 & 100.00 \\
\hline Grains/ Roots/ Tubers & 0.00 & 0.00 & 0.00 & 100.00 & 100.00 & 100.00 & 100.00 \\
\hline Legumes & 100.00 & 0.00 & 100.00 & 100.00 & 85.71 & 100.00 & 100.00 \\
\hline Milk and milk products & 0.00 & 0.00 & 0.00 & 0.00 & 42.86 & 46.67 & 100.00 \\
\hline Fleshy foods & 0.00 & 0.00 & 100.00 & 18.75 & 28.57 & 60.00 & 100.00 \\
\hline Vitamin-A rich fruits and vegetables & 0.00 & 0.00 & 0.00 & 0.00 & 57.14 & 93.33 & 100.00 \\
\hline Other fruits and vegetables & 0.00 & 0.00 & 0.00 & 81.25 & 85.71 & 100.00 & 100.00 \\
\hline Oils and fats &
\end{tabular}

Fig.1 Per cent consumption of different food groups by dietary diversity score

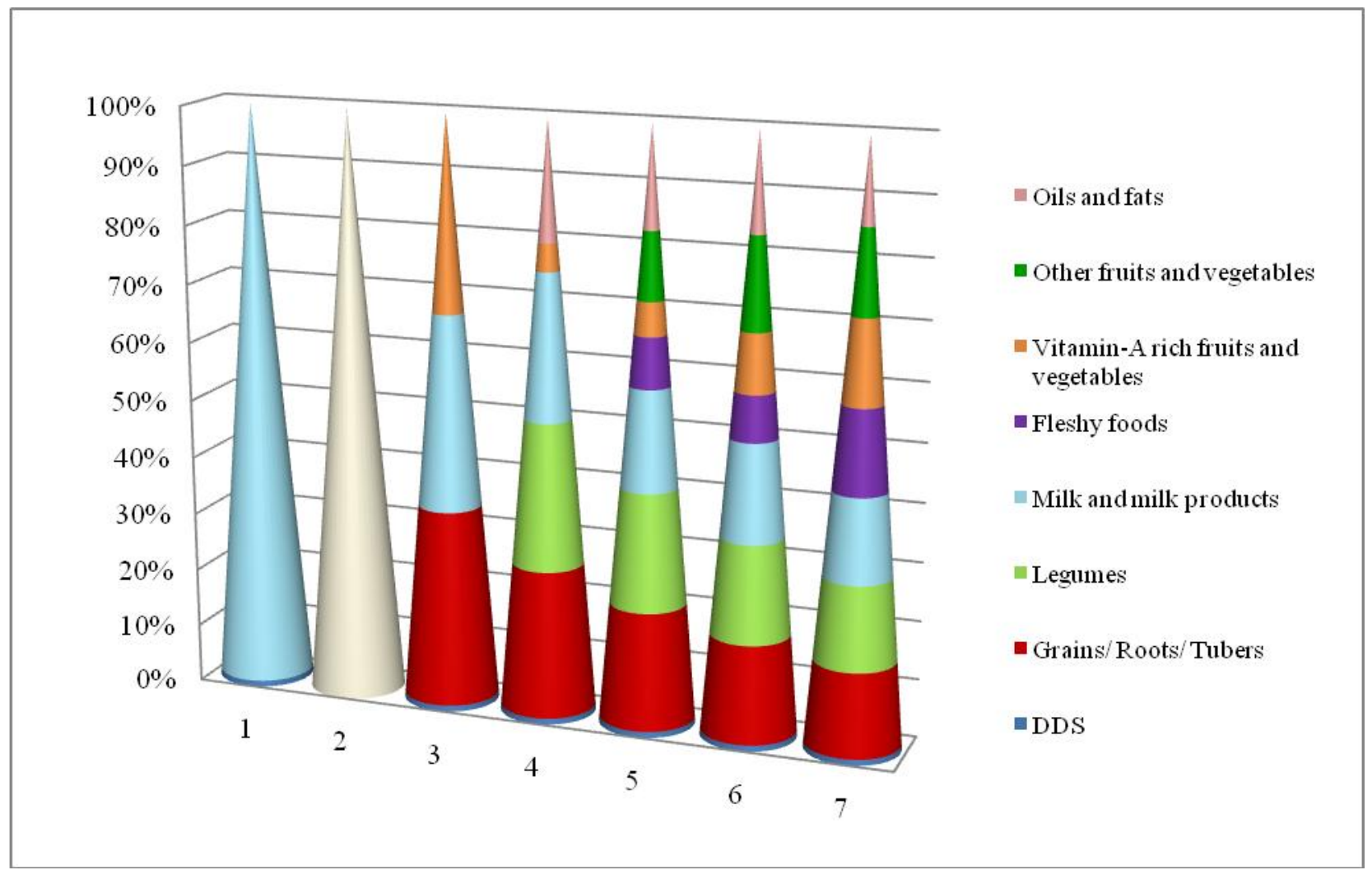

Milk and dairy goods were the most common meal types among infants and young children with the highest DDS, while fleshy foods are eaten only at greater dietary scores by a substantial part of the inhabitants (DDS $\geq 5$ ). Similarly, the DDS of fruits and vegetables rich in vitamin-A reaches more than $50 \%$ of the DDS value of 6 and above. Legumes achieve $100 \%$ of the 4 th and above DDS value. It is in line with Moursi et al., (2008) research that grains, roots and tubers were the primary source of nutrition at the DDS of 1 . More than half of the kids eaten other fruits and vegetables at DDS of 2 and $>90$ percent 
at a rating of 4 . At DDS of 4 and greater, at least half of the kids were eaten fleshy foods.

In the case of the number of food groups consumed, $50 \%$ of children in their daily diet do not receive at least 5 food groups. If not, the macro and micro nutrients will definitely be in deficient quantities that will influence the nutrient metabolic processes that adversely influence children's growth and development.

\section{References}

Arimond, M. and Ruel, M., Dietary diversity is associated with child nutritional status evidence from 11 demographic and health surveys. Journal of Nutrition, 2004, 134: 2579-2585.

Gittelsohn, J., Mookherji, S. and Pelto, G., Operationalizing household food security inrural Nepal, Food and Nutrition Bulletin, 1998, 19: 210-22.

Hatløy, A., Hallund, J., Diarra, M.M. and Oshaug, A. Food variety, socioeconomic status and nutritional status in urban and rural areas in Koutiala (Mali), Public Health Nutrition, 2000, 3: 57-65.

Hoddinott, J. and Yohannes, Y. (2002), Dietary Diversity as a Food Security Indicator, International Food Policy Research Institute/Food Consumption and Nutrition Division, Washington, DC, p. 40.

Jayawardena, R., Byrne, N. M., Soares, M. J., Katulanda, P., Yadav, B. and Hills, A. P., High dietary diversity is associated with obesity in Sri Lankan adults: an evaluation of the dietary scores. $B M C$ Public Health 2013, 13: 314

Moursi, M. M., Arimond, M., Dewey, G., Ruel, M. T. and Delpeuch, F. Dietary diversity is a good predictor of the micronutrient density of the diet of 6 to 23 month old children in Madagascar. Journal of Nutrition, 2008, 138: 24482453.

Muthayya, S., Rah, J.H., Sugimoto, J.D., Roos, F.F. Kraemer, K., The global hidden hunger indices and maps: an advocacy tool for action. Plos one, 2013, 8: 7860.

National Family Health Survey (NFHS), International Institute for Population Sciences, Govandi Station Road, Deonar, Mumbai, Maharashtra. 201516.

Stratton, R.J., Green, C.J. and Elia, M., Scientific criteria for defining malnutrition disease-related malnutrition. An evidence based approach to treatment. CABI publishing, Wallingford 2003.

Torheim, L.E., Ouattara, F., Diarra, M.M., Thiam, F.D., Barikmo, I., Hatløy, A. and Oshaug, A., Nutrient adequacy and dietary diversity in rural Mali: association and determinants, European Journal of Clinical Nutrition, 2004, 58: 594-604.

WHO/UNICEF, (1998) Complementary feeding of young children in developing countries: a review of current scientific knowledge. (WHO/NUT/98.1) Geneva: World Health Organization.

World bank data (2016), Malnutrition in India statistics- State wise

\section{How to cite this article:}

Lavanya Nallasamy, Usha Singh and Sunita Kumari. 2019. A Critical Analysis of Diet Diversity among Infants and Young Children Aged 6-24 Months. Int.J.Curr.Microbiol.App.Sci. 8(08): 1068-1073. doi: https://doi.org/10.20546/ijcmas.2019.808.124 